Subjective Attribution of Infectious Disease Outbreaks to Climate Change is Associated with Mitigation Behavioural Intentions and COVID-19 Recovery Policy Support

\author{
Jagadish Thaker \\ School of Communication, Journalism \& Marketing, Massey University \\ (THIS MANUSCRIPT IS UNDER REVIEW)
}

\begin{abstract}
Author Note
Jagadish Thaker (iD https://orcid.org/0000-0003-4589-7512

The author has no known conflict of interest to disclose. Funding for the data collection was sponsored by Massey University.

Corresponding concerning this article should be addressed to Dr. Jagadish Thaker, Senior Lecturer, School of Communication, Journalism \& Marketing (Te Pou Aro Korero), Massey University, Private Bag 756, Wellington 6140. Email: jthaker@ massey.ac.nz
\end{abstract}




\begin{abstract}
Scholars argue that personal experience with climate change related impacts has the potential to increase public engagement. Yet, previous studies, which have almost exclusively focussed on experience with extreme weather events, provide mixed results. Based on experiential learning and attribution theory, this article argues that unless individuals' attribute an event as related to or caused by climate change, their responses may be misdirected. Results based on survey data from a nationally representative sample of the New Zealand public indicates that subjective attribution of infectious disease outbreaks to climate change and to the human impact on the environment is positively associated with mitigation behavioural intentions and policy support. In addition, political affiliation moderates the relationship between subjective attribution and mitigation policy support, indicating a higher potential for right-leaning compared to moderates or left-leaning respondents to learn about climate change through health-related climate change impacts. Helping people understand the role of human impact on the environment and climate change in infectious disease outbreaks is likely to increase public engagement.
\end{abstract}

Keywords: COVID-19, infectious diseases, subjective attribution, climate change, behavioural intentions, policy support, political affiliation

\title{
Highlights:
}

Subjective attribution of infectious disease outbreaks to human impact on the environment is associated with mitigation behavioural intentions and policy support.

Subjective attribution of infectious disease outbreaks to climate change is associated with mitigation behavioural intentions and policy support.

Political affiliation moderates the association between subjective attribution and policy support but not behavioural intentions. 


\section{Subjective Attribution of Infectious Disease Outbreaks to Climate Change is Associated with Mitigation Behavioural Intentions and COVID-19 Recovery Policy Support}

\section{Introduction}

The coronavirus disease 2019 (COVID-19) pandemic is continuing to have an unprecedented impact on public health and the global economy. According to the World Health Organization, while there is no direct link between climate change and COVID-19, the disease caused by the coronavirus SARS-CoV-2, "most emerging infectious diseases, and almost all recent pandemics, originate in wildlife, and there is evidence that increasing human pressure on the natural environment may drive disease emergence" (World Health Organization, 2020, para 3). Climate change influences many socio-ecological components, increasing the risk of infectious diseases for humans, wildlife, livestock, and plants (Campbell-Lendrum et al., 2015; Ostfeld, 2017; Wu et al., 2016). Climate change can impact human health directly by influencing the growth, survival, transmission and virulence of disease-causing pathogens or indirectly through "climate-related perturbations in local ecosystems or the habitat of species that act as zoonotic reservoirs" (Smith et al., 2014, p, 726). A majority of emerging infectious diseases, and almost all recent pandemics such as SARS, MERS, West Nile, H1N1, and Ebola, originate in animals ("zoonotic disease" or “zoonosis").

The global economic cost of the COVID-19 pandemic is estimated to reach $\$ 9$ trillion (Battersby et al., 2020). As countries race to support COVID-19 economic recovery, it is important that these policies also address the global crisis of climate change (Hepburn et al., 2020; Rosenbloom \& Markard, 2020) and human impact on the environment or risk further disease outbreaks (Morens \& Fauci, 2020). Scholars have identified five COVID-19 fiscal recovery policies with high potential on both economic multiplier and climate impact metrics: clean physical infrastructure, building efficiency retrofits, investment in education and 
training, natural capital investment, and clean energy research and development (Hepburn et al., 2020). The United Nations also urges bold action to ensure COVID-19 recovery is aligned with Sustainable Development Goals (UN, 2020). Public support in enacting and implementing these policies is critical to achieving success as public opinion shapes government enactment of environmental policies (e.g., Anderson et al., 2017; Hepburn et al., 2020). The focus of this study is to understand if people subjectively attribute the emergence of infectious diseases such as the COVID-19 to the human impact on the environment and climate change, and how such a cognitive assessment shapes mitigation behaviour change and support for climate-focussed COVID-19 economic recovery policies.

A burgeoning number of studies have evaluated how public experiences climate change and how such an experience shapes individuals' beliefs, behaviours, and mitigation policy support (Akerlof et al., 2013; Demski et al., 2017; Linden, 2014; Marlon et al., 2019; Myers et al., 2013; Ogunbode et al., 2019; Osaka \& Bellamy, 2020; Reser \& Bradley, 2020; Zanocco et al., 2019). The primary rationale of these studies is that personal experience activates experiential processing of complex scientific information such as climate change, which provides a more powerful stimulus for public understanding and engagement with the issue (e.g., Marx et al., 2007; Weber, 2006).

Research on personal experiences of climate change, however, has almost exclusively focused on individuals' experiences with weather anomalies and extreme weather events in shaping public responses to climate change (Howe \& Leiserowitz, 2013; Howe et al., 2019; McCright et al., 2014; Ogunbode et al., 2019, 2019; Reser \& Bradley, 2020). Extreme weather events provide a visceral and localised experience for individuals to interpret a global phenomenon such as climate change, thereby increasing issue salience and mitigation actions. 
Empirical evidence is mixed, however. While some studies find that personal experience of extreme weather events is associated with concern, mitigation behavioural intensions and policy support (Demski et al., 2017; Hamilton-Webb et al., 2017; Marx et al., 2007; Zanocco et al., 2019), others found little or no evidence (Larcom et al., 2019; Ogunbode et al., 2019; Spence et al., 2011). Prior beliefs and affective responses about climate change also structure how public experience and respond (McCright et al., 2014; Myers et al., 2013; Ogunbode et al., 2019; Reser \& Bradley, 2020). More simply, preexisting climate change beliefs, values, worldviews, and political orientation structure how individuals' experience, interpret, assimilate, and respond to personal experiences with climate change related impacts.

More recent studies indicate that a key link to explain the dissonance in findings between personal experience and beliefs is subjective attribution (McCright et al., 2014; Ogunbode et al., 2019, 2020b; van der Linden, 2014). Subjective attribution is defined as "a personal understanding that an extreme weather event is causally connected to climate or is a sign of climate change" (Ogunbode et al., 2019, p. 32). Research that focuses on objective measures of exposure — such as individuals living in an area that was recently flooded or experienced drought conditions-ignores the inherently subjective nature of experience (Reser \& Bradley, 2020). Unless individuals can connect their personal experience of extreme weather events as being associated with climate change, experience alone may not be instrumental in shaping climate change related actions; instead, actions may reflect normal practices (Hamilton-Webb et al., 2017) or the events may be attributed to other causes, such as poor infrastructure management (Ogunbode et al., 2019), thereby deflecting attention from climate-related behaviours and policies. It is important to note that subjective attribution can be independent of, and different to, scientific attribution that an event is caused or influenced 
by climate change. Subjective experience and attribution, however, is at the core of how individuals make sense of and respond to events (Reser \& Bradley, 2020).

This study extends previous findings in several unique ways. First, it applies attribution theory (Weiner, 2006, 2011) and experiential learning about climate change (Marx et al., 2007; Weber, 2006) in a new context of health impacts of climate change — an area of study that has received scant attention by social science scholars (e.g., Akerlof et al., 2010; Clayton \& Manning, 2018; Nisbet et al., 2010) as well as little media attention about climate change impacts on health (Weathers, 2013). Understanding health impacts of climate change can be more persuasive in shaping public action compared to environmental impacts (e.g., Myers et al., 2012).

Second, scholars acknowledge that the potential for extreme weather events to act as teachable moments is limited by geography, scale of impact, and timing (McDonald et al., 2015; Reser \& Bradley, 2020; Roh et al., 2015). In contrast, the COVID-19 pandemic has impacted people all around the world, with COVID-19 cases reported in 227 countries and territories, and over a million deaths to date. In addition, viral images of animals straying in cities (Chalasani, 2020; Guardian, 2020), view of Himalayas even from the most polluted cities (Gettleman \& Conway, 2020), among others, in absence of usual human activity, may have explicitly, or implicitly, potentially influenced public understanding of the human impact on the environment.

Third, this study tests subjective attribution of infectious disease outbreaks such as COVID-19 with two distinct variables: a general measure of the human impact on the environment, and specifically, with climate change being linked to the rise in risks of infectious diseases. Previous studies indicate that public perceptions may differ based on how they associate with keywords such as climate change (Jang \& Hart, 2015) and how public interprets attribution of different events to climate change (Osaka \& Bellamy, 2020; Zanocco 
et al., 2019). Whether such differences manifest in how individuals subjectively attribute the rise in infectious diseases is tested in this study.

Fourth, unlike previous studies focussed on mitigation behavioural intentions and general mitigation policies, this study specifically tests these measures in the context of COVID-19 by adding specific costs and inconveniences to the question-wording on behaviours. As the measures become more specific and concrete, such as explicit personal cost for respondents and indicative price for carbon tax, the lower the association between individuals' climate change beliefs with behavioural intentions and policy support (e.g., Hornsey et al., 2016). Finally, this study seeks to clarify the role of political affiliation in moderating the influence of subjective experience on behavioural intensions and policy support, in a new context of health impact. While a majority of studies show political orientation and party affiliation is a powerful factor in moulding climate change beliefs and behaviours, including subjective attribution (e.g., McCright et al., 2014; Ogunbode et al., 2019), more recent studies demonstrate the potential of subjective experience to override political partisanship (Ogunbode et al., 2020; Zanocco et al., 2019). Using data from a nationally representative sample survey in New Zealand, this study tests if subjective attribution of infectious diseases such as COVID-19 to the anthropogenic impact on the environment and subjective attribution to climate change is associated with mitigation behavioural intentions and mitigation policy support.

H1: Subjective attribution of infectious disease outbreaks to human impact on the environment will be positively associated with mitigation behavioural intentions and mitigation policy support.

$\mathrm{H} 2$ : Subjective attribution of infectious disease outbreaks to climate change will be positively associated with mitigation behavioural intentions and mitigation policy support. 
H3: Subjective attribution of infectious disease outbreaks to human impact on the environment will have a stronger direct association with mitigation behavioural intentions and mitigation policy support among left-leaning compared to right-leaning respondents.

H4: Subjective attribution of infectious disease outbreaks to climate change will have a stronger direct association with mitigation behavioural intentions and mitigation policy support among left-leaning compared to right-leaning respondents.

\section{Method}

The data for this study comes from a nationally representative sample survey of 1040 New Zealand adults, aged 18 and older. The self-administered web-based survey was fielded by Qualtrics, an international survey agency, between June 26 to July 13, 2020, just after New Zealand's national lockdown was lifted and the country returned to some degree of normality. The survey took about 22 minutes on average to complete. The data were weighted, post-survey, on gender, age, education, and ethnicity to match the New Zealand census estimates. See Table 1 for a summary of demographic variables.

\subsection{Measures}

The wording of the questions, the range of responses, and other descriptive information is provided in Table 2. Two distinct subjective attribution measures were used in the study: (1) human impact on the environment and (2) climate change. Principal axis factor analysis with direct oblimin rotation, to account for correlation between the variables, was used to verify if the variables represent distinct factors. Kaiser-Meyer-Olkin measure of sampling adequacy was .89 , above the commonly recommended value of .6, and Bartlett's test of sphericity was significant $(\chi 2(28)=5843.97, p<.001)$. Two factors explained $75 \%$ of the variance (see Supplementary Table 1). The mean of the variables that comprised the two factors was computed for analysis, respectively. 
Mitigation policy support variables were operationalized based on the Oxford University study that suggested five policy measures to address economic recovery from COVID-19 aligned with climate action, as mentioned in the Introduction section (Hepburn et al., 2020). Mitigation behavioural intensions variables were used following previous studies (Ballew et al., 2020; Leiserowitz, 2006; Ogunbode et al., 2019). Importantly, these measures contained a cost or inconvenience factor (Hornsey et al., 2016).

Following previous research in the UK (Ogunbode et al., 2019) and New Zealand (Milfont et al., 2012), declared voting intentions for the upcoming national elections were used to categorize political affiliation. Scholars argue that in New Zealand, political polarisation, along the liberal to conservative axis, is not as pronounced as in the US. Instead, political party support has been used and shown to reflect political orientation in New Zealand, particularly on the issue of climate change (Milfont et al., 2012). Respondents who said they will vote for the 'Green party' or the 'Maori party' were coded as left-leaning (1), based on the assessment about their policies according to an independent organisation of 700 health professionals (Crosfield, 2020). Respondents who said they will vote for 'Labour,' a centre-left party were coded as the moderate (0), similar to previous studies (Milfont et al., 2012), and respondents who said they will vote for National, a centre-right party, along with other smaller parties that share the limited government ideal were coded as right-leaning $(-1)$. These smaller parties, such as ACT and New Conservative party, promise to repeal local environmental policies (Zero Carbon Act) and withdraw from the Paris Climate Agreement, respectively.

Several demographic variables were controlled for in the study, including, gender, age, income, education. The following variables were dummy coded: marital status (married/with partner, de-facto $=1$, versus others coded as 0 ), those with children $(1)$, job status (currently employed =1), membership in local groups (yes=1), and smoking status 
( smoke/roll own tobacco/vape $=1$ ). Group membership was used to account for networks of social support and learning, and smoking status was used to account for higher susceptibility to COVID-19 disease. Asian and other ethnicities were dummy coded in reference to European New Zealanders (European descendants or white), Māori, and Pacifika.

In addition, knowledge about COVID-19 origin, transmission, and ways to protect oneself was used to test the unique association between subjective attribution and outcome variables. Eleven questions, measured dichotomously (True or False), were used to compute knowledge about COVID-19. The scientifically accurate answers were summed to create an index of knowledge about COVID-19 $(M=9.58, S D=1.56$; KR-20 (Kuder-Richardson Formula 20) $=.58)$.

Hypotheses were tested with the PROCESS macro for regression-based estimation (Hayes, 2013), and in addition, bootstrapping with 1000 resamples were employed to ensure the robustness of the findings. Demographic variables and knowledge about COVID-19 were included as covariates in all tests.

\section{Findings}

Subjective attribution of infectious disease outbreaks to human impact on the environment

As hypothesized (H1), subjective attribution of infectious disease outbreaks to the human impact on the environment was significantly associated with mitigation policy support $(\mathrm{B}=.39, \mathrm{SE}=.03, p<.001,95 \% \mathrm{CI}:[.33, .46])$ as well as mitigation behavioural intentions $(\mathrm{B}=.29, \mathrm{SE}=.03, p<.001,95 \% \mathrm{CI}:[.24, .36])$.

Political affiliation moderated this relationship between subjective attribution and mitigation policy support $(\mathrm{B}=-.15, \mathrm{SE}=.05, p<.01,95 \% \mathrm{CI}:[-.25,-.05])$ but in the opposite direction as hypothesized (H3). Pick a point analysis was used to identify the nature of the interaction at high (mean $+1 \mathrm{SD})$, moderate (mean) and low (mean $-1 \mathrm{SD})$ levels of the moderator. The interaction was significant at the three levels but the estimate was higher at 
low $(\mathrm{B}=.48, \mathrm{SE}=.04, p<.001,95 \% \mathrm{CI}:[.39, .57])$ compared to moderate $(\mathrm{B}=.39$, $\mathrm{SE}=.03, p<.001,95 \% \mathrm{CI}:[.33, .46])$ and high levels $(\mathrm{B}=.31, \mathrm{SE}=.04, p<.001,95 \% \mathrm{CI}$ : $[.22, .39)$ of the political affiliation moderator. As the graphical illustration of the interaction illustrates, the slope of the interaction was steeper for right-leaning compared to moderates and left-leaning respondents (Figure 1).

Contrary to hypothesis 3 , political affiliation did not moderate the association between subjective attribution of infectious diseases to human impact on the environment and mitigation behavioural intentions ( $\mathrm{B}=-.03, \mathrm{SE}=.04, p=.39,95 \% \mathrm{CI}:[-.13, .05])$. In other words, hypothesis 3 was partly supported: political affiliation moderated the association between subjective attribution with policy support, but in the opposite direction, and political affiliation did not moderate the association between subjective attribution with behavioural intentions.

Subjective attribution of infectious disease outbreaks to climate change

As hypothesized (H2), subjective attribution of infectious disease outbreaks to climate change was significantly associated with mitigation policy support $(\mathrm{B}=.36$, $\mathrm{SE}=.03, p<.001,95 \% \mathrm{CI}:[.33, .46])$ as well as mitigation behavioural intentions $(\mathrm{B}=.30$, $\mathrm{SE}=.03, p<.001,95 \% \mathrm{CI}:[.24, .33])$.

Hypothesis 4 was partly supported. Among right-leaning respondents, greater acknowledgement of the role of climate change in infectious disease outbreaks was associated with greater policy support compared to moderates or left-leaning respondents. Using a similar pick-a-point approach as mentioned above, while the interaction was significant at all levels, the estimate was higher among right-leaning $(\mathrm{B}=.47$, $\mathrm{SE}=.07, p<.001,95 \% \mathrm{CI}:[.39, .55])$ compared to moderate $(\mathrm{B}=.35, \mathrm{SE}=.03, p<.001$, $95 \% \mathrm{CI}:[.31, .41])$ and the left-leaning respondents $(\mathrm{B}=.25, \mathrm{SE}=.03, p<.001,95 \% \mathrm{CI}:[.18$ $.31])$. 
Political affiliation did not moderate the association between subjective attribution of infectious diseases to climate change and mitigation behavioural intentions $(\mathrm{B}=-.03$, $\mathrm{SE}=.04, p=.48,95 \% \mathrm{CI}:[-.11, .05])$. Finally, limited support was found for hypothesis 5 : Knowledge about COVID-19 was negatively associated with mitigation behavioural intentions but was not significantly associated with policy support—implications are discussed below.

\section{Discussion}

Personal experiences of climate change can act as teachable moments for the public as they provide a powerful stimulus for risk appraisal (Demski et al., 2017; McDonald et al., 2015; Reser \& Bradley, 2020). Yet, empirical evidence provides mixed evidence to the nature and the role of personal experience with climate change beliefs and mitigation actions (e.g., Reser \& Bradley, 2020). While a majority of studies have focused on both objective and subjective experiences with extreme weather events, subjective attribution linking extreme weather event to climate change is a critical factor in shaping individual attitudes and support for policies (Ogunbode et al., 2019). Do individuals attribute other experiences, such as health impacts, to climate change remains untested. Based on a national survey of the New Zealand public, the results show subjectively attribution of infectious disease outbreaks to human impact on the environment was positively associated with mitigation behavioural intentions and mitigation policy support in the context of COVID-19 emergency economy recovery policies. In addition, subjectively attribution of infectious disease outbreaks to climate change was significantly associated with motivation to undertake mitigation behaviours, even if these were associated with additional costs or were inconvenient, and support clean and green COVID-19 recovery policies.

Subjective attribution has emerged as a key area of research to understand how individuals interpret their personal experiences with climate impacts and rationalize their 
actions (e.g., Ogunbode et al., 2019; van der Linden, 2014). Several studies indicate that exposure to extreme weather events — measured through objective indicators — find weak or no association with climate change attitudes and behaviours (e.g., Howe et al., 2019), even an inverse relationship (Ogunbode et al., 2020a). In contrast, subjective experience of extreme weather events, for example in terms of individual flooding experience, perceived personal harm, and property loss, are a more proximate source of influence on risk appraisals and subsequent protective behaviours (Marlon et al., 2019; Ogunbode et al., 2020b; Zanocco et al., 2019). Yet, if such experience does not result in attributing to appropriate causes, individuals are less likely to align their behaviours with actions needed to protect from a similar experience (Hamilton-Webb et al., 2017; McCright et al., 2014; Ogunbode et al., 2019). In other words, unless the link between experience (e.g., extreme weather event) and cause of the event (e.g., climate change) is salient, the experience is likely to drive risk perceptions towards the immediate risk (extreme weather, COVID-19) without necessarily driving climate change specific risk perceptions and mitigation actions (van der Linden, 2014). Causal attribution is a core aspect of how individuals make sense of and respond to a personal experience.

This study extends previous findings that have almost exclusively focused on the role of experiential learning and psychological proximity primarily in the domain of extreme weather events and climate change perceptions. Apart from extreme weather events, individuals can personally experience climate change through a variety of other climate signals. One such promising domain is public perceptions about health impacts of climate change - an area that has received scant scholarly attention even as scientific evidence on the complex interweb between climate, environment, and human factors has gained momentum (Campbell-Lendrum et al., 2015; Lustgarten, 2020; Ostfeld, 2017; World Health Organization, 2020; Wu et al., 2016). As health impacts are more persuasive than 
environmental frames, particularly among those are sceptical about climate change (Myers et al., 2012), the findings of this study indicate that understanding how individuals attribute health impacts associated with climate change can be a useful avenue for future research. The findings of this study add to the knowledge about factors that shape citizens support for climate change policies, more urgent now as governments strive to rebuild the economy. The coronavirus pandemic provides an opportunity to build an economy that is resilient to immediate economic impacts as well as climate-proof for future impacts (Hepburn et al., 2020; UN 2020).

Scholars agree that learning about climate change from extreme weather hazards are usually time and geographically bound, even as individuals can learn from vicarious experiences through media. COVID 19 is likely the most widespread globally shared experience of a hazard event in recent history that has been reinforced with continuous exposure to media coverage of the pandemic. Over 35.5 million cases and 1 million deaths have been reported in 227 countries and territories. Apart from deaths of family and friends, the nature of lockdown in different countries, with restricted travel not just across borders but across neighbourhoods, provided a powerful personal experience with a global issue. Individuals potentially learned vicariously about the human impact on the environment through viral images of animals occupying city streets (Chalasani, 2020; Guardian, 2020), clear skies even in most polluted cities (Gettleman \& Conway, 2020). This is in line with other surveys that show that public concern about climate change has increased after COVID19 (Morton, 2020; Poushter et al., 2020). This study indicates the potential to explore how subjective attribution of health impacts due to a global problem such as climate change can provide a powerful stimulus to help people learn about climate change specifically, and human impact on the environment, generally. Factor analysis confirms that subjective 
attribution of infectious diseases to human impact on the environment and subjective attribution of infectious diseases to climate change are two distinct dimensions.

Several studies indicate that political affiliation trumps potential to learn about climate change through personal experience (Hornsey et al., 2016; McCright et al., 2014; McCright \& Dunlap, 2011; Ogunbode et al., 2019; Roh et al., 2015). However, only a few studies have focused on how subjective attribution to climate change is shaped by political orientation (McCright et al., 2014; Ogunbode et al., 2020b). In contrast to the hypothesis, political affiliation moderated the association between subjective attribution and policy support but in the opposite direction. The association between subjective attribution and policy support was stronger among right-leaning than moderate and left-leaning respondents. This finding is consistent with recent research in the US that shows that for conservatives or Republicans, higher levels of personal harm was associated with greater mitigation policy support (Zanocco et al., 2019). In other words, increasing experience to impacts of climate change may reduce the political divide in how individuals make sense of climate change and their support for mitigation policies (Ogunbode et al., 2020b; Zanocco et al., 2019).

However, political affiliation did not moderate the relationship between subjective attribution and mitigation behavioural intentions. It is possible that political affiliation may be activated when individuals are focussing on public policy rather than on personal behaviours. It is also possible that as the measure of political affiliation used in the study was based on party affiliation, the ideological difference was manifested on policy support but not on behavioural intensions. It is important for future research to distangle the difference in association between party affiliation and political orientation with climate change related behaviours and policy support. For example, Zanocco et al., (2019) did not find a difference in association between either using party identification (Republican) or political ideology (conservative) in association with policy support, but they did not evaluate behavioural 
intentions. In a recent meta-analysis, Cruz (2017) found that the association between party affiliation and environmental concern has strengthened over time, while the association between political ideology and environment concern has largely remained the same. Cruz (2017) and Ogunbode et al., (2019) imply that the increasing gap between party affiliation and public attitudes towards environmental issues is a result of changing voting patterns, rather than attitude change. Future research can help better understand the difference between party affiliation and ideological orientation in shaping climate change mitigation responses in New Zealand. In addition, there is a need to replicate the findings of this study in more polarised countries, such as the US, and in multi-party democracies such as the UK to assess the role of party affiliation and political ideology in shaping public mitigation responses.

In a surprising finding, knowledge about COVID-19 was not associated with policy support but had a small negative association with mitigation behaviour intentions. This finding illustrates that knowledge alone may have little or no influence on how the public engages with an issue, including as global and visceral such as the COVID-19 pandemic. Previous studies have found limited or no association between knowledge about climate change and mitigation behaviours and policy support (Hornsey et al., 2016; Rhodes et al., 2014). This finding further highlights that experiential processing, particularly subjective attribution, plays a key role in how individuals make sense of and respond to their experiences.

On a practical note, helping people understand the links between the human impact on the environment and climate change with infectious disease outbreaks is likely to help increase public understanding and engagement (Amelung et al., 2019; Roh et al., 2015; Shreedhar \& Mourato, 2020). Scholars have suggested that emphasising the links between experiences of extreme weather events and climate change facilitates a congruent cognitionemotion link, likely the most successful approach (van der Linden, 2014). Linking climate 
policies with direct health impacts can increase individual private behavioural change as well as policy support (Amelung et al., 2019). Apart from personal experience, people learn from vicarious experiences, through media for example. However, we may have missed an important opportunity to engage the public with the bigger crisis of climate change during the COVID-19 pandemic. News coverage of climate change has decreased during the COVID-19 pandemic (Boykoff et al., 2020).

A potential threat to the findings of this study is that individuals may readily attribute negative events to climate change. Previous surveys, however, in the UK about flooding (Capstick et al., 2015; Hamilton-Webb et al., 2017; Ogunbode et al., 2019) and heat waves (Larcom et al., 2019) and the US about California drought (Osaka \& Bellamy, 2020) show that individuals are hesitant to attribute these extreme weather events to anthropogenic climate change. Lack of climate change measures in the survey is also a limitation as climatechange specific beliefs may help explain how these interact with subjective attribution on the one hand, and mitigation behaviour intentions and policy support on the other. Other factors that may influence how public attributes events to climate change are perceived government response, where appropriate government response likely decreases the public need to find causes or resolutions for negative events (Zanocco et a., 2019). Yet, the New Zealand government has been universally praised for its role in keeping the infection rates low and deaths limited to 25 even after eight months of the global spread of the COVID-19 disease. A more comprehensive framework of climate change beliefs, values, and worldviews will better help understand the antecedents and consequences of subjective attribution.

\section{Conclusion}

A primary challenge to communicating climate change is its abstract, global, longterm impact. With climate impacts becoming more apparent, such as weather anomalies and extreme weather events, individual responses are likely to be more emotionally charged that 
can drive public engagement. However, unless individuals' attribute these events as related to anthropogenic climate change, public responses may be misdirected. This study finds that subjective attribution of infectious disease outbreaks such as the COVID-19 to climate change is associated with mitigation behaviour intentions and mitigation policy support. Scientific attribution of events as caused or influenced by climate change and individuals' causal attributions are likely to be different. Nevertheless, subjective attribution is important in shaping public responses. 


\section{References}

Akerlof, K., DeBono, R., Berry, P., Leiserowitz, A., Roser-Renouf, C., Clarke, K.-L., Rogaeva, A., Nisbet, M. C., Weathers, M. R., \& Maibach, E. W. (2010). Public perceptions of climate change as a human health risk: Surveys of the United States, Canada and Malta. International Journal of Environmental Research and Public Health, 7, 2559-2606. https://doi.org/10.3390/ijerph7062559

Akerlof, K., Maibach, E. W., Fitzgerald, D., Cedeno, A. Y., \& Neuman, A. (2013). Do people "personally experience" global warming, and if so how, and does it matter? Global Environmental Change, 23(1), 81-91. https://doi.org/10.1016/j.gloenvcha.2012.07.006

Amelung, D., Fischer, H., Herrmann, A., Aall, C., Louis, V. R., Becher, H., Wilkinson, P., \& Sauerborn, R. (2019). Human health as a motivator for climate change mitigation: Results from four European high-income countries. Global Environmental Change, 57, 101918. https://doi.org/10.1016/j.gloenvcha.2019.05.002

Anderson, B., Böhmelt, T., \& Ward, H. (2017). Public opinion and environmental policy output: A cross-national analysis of energy policies in Europe. Environmental Research Letters, 12(11), 114011. https://doi.org/10.1088/1748-9326/aa8f80

Battersby, B., Lam, W. R., \& Ture, E. (2020, May 20). Tracking the \$9 Trillion Global Fiscal Support to Fight COVID-19. IMF Blog. https://blogs.imf.org/2020/05/20/trackingthe-9-trillion-global-fiscal-support-to-fight-covid-19/

Bord, R. J., O’Connor, R. E., \& Fisher, A. (2000). In what sense does the public need to understand global climate change? Public Understanding of Science, 9(3), 205-218.

Campbell-Lendrum, D., Manga, L., Bagayoko, M., \& Sommerfeld, J. (2015). Climate change and vector-borne diseases: What are the implications for public health research and policy? Philosophical Transactions of the Royal Society B: Biological Sciences, 370(1665), 20130552. https://doi.org/10.1098/rstb.2013.0552

Capstick, S. B., Demski, C. C., Sposato, R. G., Pidgeon, N. F., Spence, A., \& Corner, A. (2015). Public perceptions of climate change in Britain following the winter 2013. 2014.

Capstick, S., Whitmarsh, L., Poortinga, W., Pidgeon, N., \& Upham, P. (2015). International trends in public perceptions of climate change over the past quarter century. Wiley Interdisciplinary Reviews: Climate Change, 6(1), 35-61. https://doi.org/10.1002/wcc.321

Chalasani, R. (2020, April 22). Photos: Wildlife roams during the coronavirus pandemic. ABC News. https://abcnews.go.com/International/photos-wildlife-roams-planetshuman-population-isolates/story?id=70213431

Clayton, S., \& Manning, C. (Eds.). (2018). Psychology and climate change: Human perceptions, impacts, and responses (1st Edition). Academic Press.

Crosfield, J. (2020, September 28). Scorecard for NZ election 2020-Climate change and health. OraTaiao. http://www.orataiao.org.nz/nz_election_2020_scorecard_climate_change_and_health

Cruz, S. M. (2017). The relationships of political ideology and party affiliation with environmental concern: A meta-analysis. Journal of Environmental Psychology, 53, 81-91. https://doi.org/10.1016/j.jenvp.2017.06.010

Cutler, M. J., Marlon, J., Howe, P., \& Leiserowitz, A. (2020). 'Is global warming affecting the weather?' Evidence for increased attribution beliefs among coastal versus inland US residents. Environmental Sociology, 6(1), 6-18. https://doi.org/10.1080/23251042.2019.1690725 
Demski, C., Capstick, S., Pidgeon, N., Sposato, R. G., \& Spence, A. (2017). Experience of extreme weather affects climate change mitigation and adaptation responses. Climatic Change, 140(2), 149-164. https://doi.org/10.1007/s10584-016-1837-4

Gettleman, J., \& Conway, R. (2020, May 19). India Savors a Rare Upside to Coronavirus: Clean Air. The New York Times. https://www.nytimes.com/2020/04/08/world/asia/india-pollution-coronavirus.html

Gifford, R. (2011). The dragons of inaction: Psychological barriers that limit climate change mitigation and adaptation. American Psychologist, 66(4), 290-302. https://doi.org/10.1037/a0023566

Guardian. (2020, April 22). The urban wild: Animals take to the streets amid lockdown - in pictures. The Guardian.

https://www.theguardian.com/world/gallery/2020/apr/22/animals-roaming-streetscoronavirus-lockdown-photos

Hamilton-Webb, A., Manning, L., Naylor, R., \& Conway, J. (2017). The relationship between risk experience and risk response: A study of farmers and climate change. Journal of Risk Research, 20(11), 1379-1393. https://doi.org/10.1080/13669877.2016.1153506

Hayes, A. F. (2013). Introduction to mediation, moderation, and conditional process analysis: A regression-based approach. Guilford Press.

Hepburn, C., O’Callaghan, B., Stern, N., Stiglitz, J., \& Zenghelis, D. (2020). Will COVID-19 fiscal recovery packages accelerate or retard progress on climate change? Oxford Review of Economic Policy, 36(Supplement_1), S359-S381. https://doi.org/10.1093/oxrep/graa015

Hoogendoorn, G., Sütterlin, B., \& Siegrist, M. (2020). The climate change beliefs fallacy: The influence of climate change beliefs on the perceived consequences of climate change. Journal of Risk Research, O(0), 1-13. https://doi.org/10.1080/13669877.2020.1749114

Hornsey, M. J., Harris, E. A., Bain, P. G., \& Fielding, K. S. (2016). Meta-analyses of the determinants and outcomes of belief in climate change. Nature Climate Change, 6(6), 622-626. https://doi.org/10.1038/nclimate2943

Howe, P. D., \& Leiserowitz, A. (2013). Who remembers a hot summer or a cold winter? The asymmetric effect of beliefs about global warming on perceptions of local climate conditions in the U.S. Global Environmental Change, 23(6), 1488-1500. https://doi.org/10.1016/j.gloenvcha.2013.09.014

Howe, P. D., Marlon, J. R., Mildenberger, M., \& Shield, B. S. (2019). How will climate change shape climate opinion? Environmental Research Letters, 14(11), Article 11. Scopus. https://doi.org/10.1088/1748-9326/ab466a

Jang, S. M. (2013). Framing responsibility in climate change discourse: Ethnocentric attribution bias, perceived causes, and policy attitudes. Journal of Environmental Psychology, 36, 27-36. https://doi.org/10.1016/j.jenvp.2013.07.003

Jang, S. M., \& Hart, P. S. (2015). Polarized frames on "climate change" and "global warming" across countries and states: Evidence from Twitter big data. Global Environmental Change, 32, 11-17. https://doi.org/10.1016/j.gloenvcha.2015.02.010

Larcom, S., She, P.-W., \& van Gevelt, T. (2019). The UK summer heatwave of 2018 and public concern over energy security. Nature Climate Change, 9(5), 370-373. https://doi.org/10.1038/s41558-019-0460-6

Lee, T. M., Markowitz, E. M., Howe, P. D., Ko, C.-Y., \& Leiserowitz, A. A. (2015). Predictors of public climate change awareness and risk perception around the world. Nature Clim. Change, 5(11), 1014-1020. 
Leiserowitz, A. (2006). Climate change risk perception and policy preferences: The role of affect, imagery, and values. Climatic Change, 77(1), 45-72.

Leiserowitz, Anthony, \& Smith, N. (2017). Affective imagery, risk perceptions, and climate change communication. Oxford Research Encyclopedia of Climate Science. https://doi.org/10.1093/acrefore/9780190228620.013.307

Linden, S. van der. (2014). On the relationship between personal experience, affect and risk perception:The case of climate change. European Journal of Social Psychology, 44(5), 430-440. https://doi.org/10.1002/ejsp.2008

Lustgarten, A. (2020, June 5). How climate change is contributing to skyrocketing rates of infectious disease. ProPublica. https://www.propublica.org/article/climate-infectiousdiseases

Marlon, J. R., Linden, S. van der, Howe, P. D., Leiserowitz, A., Woo, S. H. L., \& Broad, K. (2019). Detecting local environmental change: The role of experience in shaping risk judgments about global warming. Journal of Risk Research, 22(7), 936-950. https://doi.org/10.1080/13669877.2018.1430051

Marx, S. M., Weber, E. U., Orlove, B. S., Leiserowitz, A., Krantz, D. H., Roncoli, C., \& Phillips, J. (2007). Communication and mental processes: Experiential and analytic processing of uncertain climate information. Global Environmental Change, 17(1), 47-58. https://doi.org/10.1016/j.gloenvcha.2006.10.004

McCright, A. M., \& Dunlap, R. E. (2011). The politicization of climate change and polarization in the American public's views of global warming, 2001-2010. The Sociological Quarterly, 52(2), 155-194. https://doi.org/10.1111/j.15338525.2011.01198.x

McCright, A. M., Dunlap, R. E., \& Xiao, C. (2014). The impacts of temperature anomalies and political orientation on perceived winter warming. Nature Climate Change, 4(12), 1077-1081. https://doi.org/10.1038/nclimate2443

McDonald, R. I., Chai, H. Y., \& Newell, B. R. (2015). Personal experience and the 'psychological distance' of climate change: An integrative review. Journal of Environmental Psychology, 44, 109-118. https://doi.org/10.1016/j.jenvp.2015.10.003

Milfont, T. L., Harré, N., Sibley, C. G., \& Duckitt, J. (2012). The climate-change dilemma: Examining the association between parental status and political party support. Journal of Applied Social Psychology, 42(10), 2386-2410. https://doi.org/10.1111/j.15591816.2012.00946.x

Morens, D. M., \& Fauci, A. S. (2020). Emerging pandemic diseases: How we got to COVID19. Cell, 182(5), 1077-1092. https://doi.org/10.1016/j.cell.2020.08.021

Morton, J. (2020, July 28). Covid-19 leaves more Kiwis worried about climate change-Poll. NZ Herald. https://www.nzherald.co.nz/nz/covid-19-leaves-more-kiwis-worriedabout-climate-change-poll/7TLZPUKKLRVHYBAZXPZGQFPFUI/

Myers, T. A., Maibach, E. W., Roser-Renouf, C., Akerlof, K., \& Leiserowitz, A. A. (2013). The relationship between personal experience and belief in the reality of global warming. Nature Clim. Change, 3(4), 343-347. https://doi.org/10.1038/nclimate1754

Myers, T. A., Nisbet, M. C., Maibach, E. W., \& Leiserowitz, A. A. (2012). A public health frame arouses hopeful emotions about climate change. Climatic Change, 113(3), 1105-1112. https://doi.org/10.1007/s10584-012-0513-6

Nisbet, M. C., Price, S., Pascual-Ferra, P., \& Maibach, E. (2010). Communicating the Public Health Relevance of Climate Change: A News Agenda Building Analysis. Sci. Commun.

Ogunbode, C. A., Demski, C., Capstick, S. B., \& Sposato, R. G. (2019). Attribution matters: Revisiting the link between extreme weather experience and climate change 
mitigation responses. Global Environmental Change, 54, 31-39.

https://doi.org/10.1016/j.gloenvcha.2018.11.005

Ogunbode, C. A., Doran, R., \& Böhm, G. (2020a). Exposure to the IPCC special report on $1.5^{\circ} \mathrm{C}$ global warming is linked to perceived threat and increased concern about climate change. Climatic Change, 158(3), 361-375. https://doi.org/10.1007/s10584019-02609-0

Ogunbode, C. A., Doran, R., \& Böhm, G. (2020b). Individual and local flooding experiences are differentially associated with subjective attribution and climate change concern. Climatic Change. https://doi.org/10.1007/s10584-020-02793-4

Osaka, S., \& Bellamy, R. (2020). Natural variability or climate change? Stakeholder and citizen perceptions of extreme event attribution. Global Environmental Change, 62, 102070. https://doi.org/10.1016/j.gloenvcha.2020.102070

Ostfeld, R. S. (2017). Biodiversity loss and the ecology of infectious disease. The Lancet Planetary Health, 1(1), e2-e3. https://doi.org/10.1016/S2542-5196(17)30010-4

Poushter, J., Huang, C., \& Inquiries, D. 20036USA202-419-4300 | M.-857-8562 | F.-4194372 | M. (2020, September 9). Despite pandemic, many Europeans still see climate change as greatest threat to their countries. Pew Research Center's Global Attitudes Project. https://www.pewresearch.org/global/2020/09/09/despite-pandemic-manyeuropeans-still-see-climate-change-as-greatest-threat-to-their-countries/

Reser, J. P., \& Bradley, G. L. (2020). The nature, significance, and influence of perceived personal experience of climate change. WIREs Climate Change, 11(5), e668. https://doi.org/10.1002/wcc.668

Rhodes, E., Axsen, J., \& Jaccard, M. (2014). Does effective climate policy require wellinformed citizen support? Global Environmental Change, 29, 92-104. https://doi.org/10.1016/j.gloenvcha.2014.09.001

Roh, S., McComas, K. A., Rickard, L. N., \& Decker, D. J. (2015). How motivated reasoning and temporal frames may polarize opinions about wildlife disease risk. Science Communication, 37(3), 340-370. https://doi.org/10.1177/1075547015575181

Rosenbloom, D., \& Markard, J. (2020). A COVID-19 recovery for climate. Science, 368(6490), 447-447. https://doi.org/10.1126/science.abc4887

Shreedhar, G., \& Mourato, S. (2020). Linking human destruction of nature to COVID-19 increases support for wildlife conservation policies. Environmental and Resource Economics, 76(4), 963-999. https://doi.org/10.1007/s10640-020-00444-x

Spence, A., Poortinga, W., Butler, C., \& Pidgeon, N. F. (2011). Perceptions of climate change and willingness to save energy related to flood experience. Nature Climate Change, 1(1), 46-49. https://doi.org/10.1038/nclimate1059

van der Linden, S. (2014). On the relationship between personal experience, affect and risk perception:The case of climate change. European Journal of Social Psychology, 44(5), 430-440. https://doi.org/10.1002/ejsp.2008

van der Linden, S. (2015). The social-psychological determinants of climate change risk perceptions: Towards a comprehensive model. Journal of Environmental Psychology, 41, 112-124. https://doi.org/10.1016/j.jenvp.2014.11.012

Weathers, M. R. (2013). Newspaper coverage of global warming and climate change (GWCC) as a public health issue. Applied Environmental Education \& Communication, 12(1), 19-28. https://doi.org/10.1080/1533015X.2013.795829

Weber, E. U. (2006). Experience-based and description-based perceptions of long-term risk: Why global warming does not scare us (yet). Climatic Change, 77(1-2), 103-120. https://doi.org/10.1007/s10584-006-9060-3

Weiner, B. (2006). Social motivation, justice, and the moral emotions: An attributional approach. Psychology Press. 
Weiner, B. (2011). An attribution theory of motivation. Handbook of Theories of Social Psychology, 1, 135-155.

World Health Organization. (2020, April 22). Q\&A: Climate change and COVID-19. https://www.who.int/westernpacific/news/q-a-detail/q-a-on-climate-change-andcovid-19

Wu, X., Lu, Y., Zhou, S., Chen, L., \& Xu, B. (2016). Impact of climate change on human infectious diseases: Empirical evidence and human adaptation. Environment International, 86, 14-23. https://doi.org/10.1016/j.envint.2015.09.007

Zanocco, C., Boudet, H., Nilson, R., \& Flora, J. (2019). Personal harm and support for climate change mitigation policies: Evidence from 10 U.S. communities impacted by extreme weather. Global Environmental Change, 59, 101984.

https://doi.org/10.1016/j.gloenvcha.2019.101984 


\section{Tables}

Table 1

Demographics of the sample

\begin{tabular}{|c|c|c|c|c|}
\hline & \multicolumn{2}{|c|}{ Unweighted } & \multicolumn{2}{|c|}{ Weighted } \\
\hline & $N$ & $\%$ & $N$ & $\%$ \\
\hline Total & 1040 & 100 & 1040 & 100 \\
\hline \multicolumn{5}{|l|}{ Gender } \\
\hline Female & 609 & 58 & 530 & 51 \\
\hline Male & 431 & 41 & 510 & 49 \\
\hline \multicolumn{5}{|l|}{ Age } \\
\hline $18-25$ & 189 & 18 & 146 & 14 \\
\hline $26-35$ & 220 & 21 & 187 & 18 \\
\hline $36-45$ & 175 & 16 & 166 & 16 \\
\hline $46-55$ & 163 & 15 & 187 & 18 \\
\hline $56-65$ & 127 & 12 & 156 & 15 \\
\hline 66 and above & 166 & 16 & 198 & 19 \\
\hline \multicolumn{5}{|l|}{ Education } \\
\hline No qualification & 96 & 9 & 199 & 19 \\
\hline $\begin{array}{l}\text { Level } 1 \text { to Level } 6 \\
\text { diploma }\end{array}$ & 577 & 55 & 564 & 54 \\
\hline $\begin{array}{l}\text { Bachelor's degree or } \\
\text { higher }\end{array}$ & 367 & 35 & 277 & 27 \\
\hline \multicolumn{5}{|l|}{ Ethnicity } \\
\hline European New Zealander & 648 & 62 & 640 & 61 \\
\hline Māori & 139 & 13 & 170 & 16 \\
\hline Pasifika & 50 & 4 & 80 & 7 \\
\hline $\begin{array}{l}\text { Asian or Another } \\
\text { Category }\end{array}$ & 203 & 19 & 150 & 14 \\
\hline \multicolumn{5}{|l|}{ Annual personal income } \\
\hline Less than $\$ 19,999$ & 280 & 26 & 286 & 27 \\
\hline$\$ 20,000$ to $\$ 39,999$ & 254 & 24 & 273 & 26 \\
\hline$\$ 40,000$ to $\$ 59,999$ & 182 & 17 & 188 & 18 \\
\hline$\$ 60,000$ to $\$ 79,999$ & 138 & 13 & 130 & 12 \\
\hline$\$ 80,000$ to $\$ 99,999$ & 68 & 6 & 59 & 5 \\
\hline$\$ 100,000$ to $\$ 119,999$ & 64 & 6 & 55 & 5 \\
\hline$\$ 120,000$ or above & 50 & 4 & 46 & 4 \\
\hline
\end{tabular}


Table 2

Tables and Measures

\begin{tabular}{|c|c|c|c|}
\hline Construct Items & $M(S D)$ & $\alpha$ & $r$ \\
\hline \multicolumn{4}{|l|}{ Subjective attribution } \\
\hline Infectious disease outbreaks and human impact on the environment & $2.77(.74)$ & 0.83 & .43 to $.77, p<.001$ \\
\hline $\begin{array}{l}\text { Human impact on the environment increases the risk of new } \\
\text { infectious diseases }\end{array}$ & $3.07(0.83)$ & & \\
\hline $\begin{array}{l}\text { Cutting forests increases the risk of new infectious diseases } \\
\text { jumping from wildlife to humans }\end{array}$ & $2.50(0.96)$ & & \\
\hline $\begin{array}{l}\text { Rapid agricultural expansion in wildlife areas makes it easier } \\
\text { for infectious diseases to spread to humans }\end{array}$ & $2.59(0.95)$ & & \\
\hline $\begin{array}{l}\text { Large-scale animal "factory" farms increase the risks of new } \\
\text { disease outbreaks }\end{array}$ & $2.92(0.92)$ & & \\
\hline Infectious disease outbreaks and climate change & $2.36(.85)$ & 0.94 & .72 to $.82, p<.001$ \\
\hline $\begin{array}{l}\text { Climate change causes the spread of infectious diseases to } \\
\text { new places }\end{array}$ & $2.30(0.91)$ & & \\
\hline $\begin{array}{l}\text { Climate change increases the risk of new disease outbreaks } \\
\text { such as the coronavirus }\end{array}$ & $2.32(0.92)$ & & \\
\hline $\begin{array}{l}\text { Climate change is making conditions more suitable for } \\
\text { disease transmission between wildlife and humans }\end{array}$ & $2.43(0.93)$ & & \\
\hline $\begin{array}{l}\text { Climate change will result in more pandemics such as the } \\
\text { coronavirus }\end{array}$ & $2.40(0.96)$ & & \\
\hline Mitigation behavioural intensions & $2.59(0.66)$ & 0.8 & .24 to $.59, p<.001$ \\
\hline Reduce consumption of meat even if it is inconvenient & $2.32(0.98)$ & & \\
\hline Reduce food waste & $3.29(0.76)$ & & \\
\hline $\begin{array}{l}\text { Increase use of public transportation, if available in your area, } \\
\text { even if increases your travel time }\end{array}$ & $2.56(0.97)$ & & \\
\hline Reduce car use even if it is inconvenient for travel & $2.50(0.95)$ & & \\
\hline Buy an energy efficient car even if it costs more initially & $2.29(0.99)$ & & \\
\hline $\begin{array}{l}\text { Purchase energy efficient appliances even if you need to pay } \\
\text { more initially }\end{array}$ & $2.65(0.92)$ & & \\
\hline Mitigation policy support & $2.87(0.77)$ & 0.91 & .64 to $.76, p<.001$ \\
\hline $\begin{array}{l}\text { Industries that receive substantial emergency financial } \\
\text { assistance should be required to lower their carbon emissions }\end{array}$ & $2.94(0.84)$ & & \\
\hline $\begin{array}{l}\text { Funding to airlines should be based on their commitment to } \\
\text { reduce their carbon emissions }\end{array}$ & $2.83(0.89)$ & & \\
\hline $\begin{array}{l}\text { Government funding should require electric utility companies } \\
\text { to generate } 100 \% \text { of their electricity from clean energy } \\
\text { sources, like solar and wind }\end{array}$ & $2.89(0.92)$ & & \\
\hline $\begin{array}{l}\text { Support the agriculture sector only if there are concrete plans } \\
\text { to reduce environmental problems }\end{array}$ & $2.78(0.92)$ & & \\
\hline $\begin{array}{l}\text { Farmers that receive government funding should reduce } \\
\text { carbon and water pollution }\end{array}$ & $2.90(0.89)$ & & \\
\hline
\end{tabular}

Note: $N=1040$. All the above items were measured on a four-point scale, $1=$ strongly disagree, $4=$ strongly agree. The mean of the individual items was computed to represent respective scales. 
Table 3

Multiple regression analysis predicting mitigation policy support

\begin{tabular}{|c|c|c|}
\hline & $\begin{array}{l}\text { Subjective attribution of } \\
\text { infectious diseases to } \\
\text { human impact on } \\
\text { environment }\end{array}$ & $\begin{array}{l}\text { Subjective } \\
\text { attribution of } \\
\text { infectious diseases to } \\
\text { climate change }\end{array}$ \\
\hline Constant & $3.15 * * *(0.17)$ & $3.03 * * *(0.17)$ \\
\hline Female & $0.09 *(0.04)$ & $0.07(0.04)$ \\
\hline Age & $0(0.01)$ & $0.01(0.01)$ \\
\hline Education & $0.02(0.04)$ & $0.01(0.04)$ \\
\hline Income & $0.01(0.02)$ & $0.02(0.01)$ \\
\hline European New Zealander & $-0.23 * * *(0.06)$ & $-0.19 * * *(0.05)$ \\
\hline Māori & $-0.11(0.07)$ & $-0.1(0.07)$ \\
\hline Pasifika & $0.10(0.09)$ & $0.08(0.08)$ \\
\hline Employed & $-0.10 *(0.05)$ & $-0.11 *(0.04)$ \\
\hline Parental status & $-0.03(0.05)$ & $-0.03(0.05)$ \\
\hline Marital status & $-0.02(0.05)$ & $-0.01(0.04)$ \\
\hline Group membership & $-0.01(0.04)$ & $-0.02(0.04)$ \\
\hline Smoking & $0.03(0.05)$ & $0.02(0.05)$ \\
\hline COVID-19 Knowledge & $-0.02(0.01)$ & $-0.01(0.01)$ \\
\hline Political affiliation & $0.28 * * *(0.04)$ & $0.27 * * *(0.04)$ \\
\hline Human impact attribution & $0.39 * * *(0.03)$ & \\
\hline Political affiliation $*$ Human impact attribution & $-0.15 * *(0.05)$ & \\
\hline Climate change attribution & & $0.36 * * *(0.03)$ \\
\hline Political affiliation $*$ Climate change attribution & & $-0.19 * * *(0.04)$ \\
\hline$\Delta R^{2}$ & 0.28 & 0.30 \\
\hline
\end{tabular}

Note. $n=1036 . * * * p<.001, * * p<.01, * p<.05$. Gender was measured dichotomously

comparing male with female (1). The three ethnicity variables were dummy coded with Asian and other ethnicities coded as a reference category. Employed were coded as 1 for respondents who said they are currently employed compared to others (0). Parental status was coded as 1 with reference to others (0). Marital status was coded for respondents with a spouse, partner, de-facto, live-in relationship to others. Group membership was coded for respondents who said they belonged to a local club with reference to others. Respondents who smoked, rolled their own cigarettes, or vaped were coded with reference to others. 
Table 4

Multiple regression analysis predicting mitigation behavioural intentions

\begin{tabular}{|c|c|c|}
\hline & $\begin{array}{l}\text { Subjective attribution } \\
\text { of infectious diseases to } \\
\text { human impact on } \\
\text { environment }\end{array}$ & $\begin{array}{l}\text { Subjective } \\
\text { attribution of } \\
\text { infectious diseases to } \\
\text { climate change }\end{array}$ \\
\hline Constant & $2.93 * * *(0.15)$ & $2.82 * * *(0.15)$ \\
\hline Female & $0.08 *(0.04)$ & $0.07(0.04)$ \\
\hline Age & $-0.01(0.01)$ & $-0.01(0.01)$ \\
\hline Education & $0.11 * *(0.03)$ & $0.09 * *(0.04)$ \\
\hline Income & $0.01(0.01)$ & $0.02(0.01)$ \\
\hline European New Zealander & $-0.16 * *(0.05)$ & $-0.14 * *(0.05)$ \\
\hline Māori & $-0.11(0.07)$ & $-0.11(0.07)$ \\
\hline Pasifika & $-0.07(0.09)$ & $-0.08(0.1)$ \\
\hline Employed & $-0.06(0.04)$ & $-0.07(0.04)$ \\
\hline Has children & $-0.02(0.05)$ & $-0.02(0.04)$ \\
\hline Marital status & $-0.03(0.04)$ & $-0.02(0.04)$ \\
\hline Group membership & $0.11 * *(0.04)$ & $0.10 * *(0.04)$ \\
\hline Smoking status & $-0.07(0.04)$ & $-0.07(0.04)$ \\
\hline Knowledge & $-0.05 * * *(0.01)$ & $-0.04 * *(0.01)$ \\
\hline Political affiliation & $0.19 * * *(0.03)$ & $0.18 * * *(0.03)$ \\
\hline Human impact attribution & $0.30 * * *(0.03)$ & \\
\hline Political affiliation $*$ Human impact attribution & $-0.04(0.05)$ & \\
\hline Climate change attribution & & $0.29 * * *(0.02)$ \\
\hline Political affiliation $*$ Climate change attribution & & $-0.03(0.04)$ \\
\hline$\Delta R^{2}$ & 0.22 & 0.24 \\
\hline
\end{tabular}

Note. $n=1036 . * * * p<.001, * * p<.01, * p<.05$. Gender was measured dichotomously

compared male with female (1). The three ethnicity variables were dummy coded with Asian

and other ethnicities coded as a reference category. Employed were coded as 1 for

respondents who said they are currently employed compared to others. Parental status was

coded as 1 with reference to others (0). Marital status was coded for respondents with a

spouse, partner, de-facto, live-in relationship to others. Group membership was coded for

respondents who said they belonged to a local club with reference to others. Respondents

who smoked, rolled their own cigarettes, or vaped were coded with reference to others. 


\section{Figures}

\section{Figure 1}

Interaction between political affiliation and subjective attribution of infectious disease outbreaks to human impact on mitigation policy.

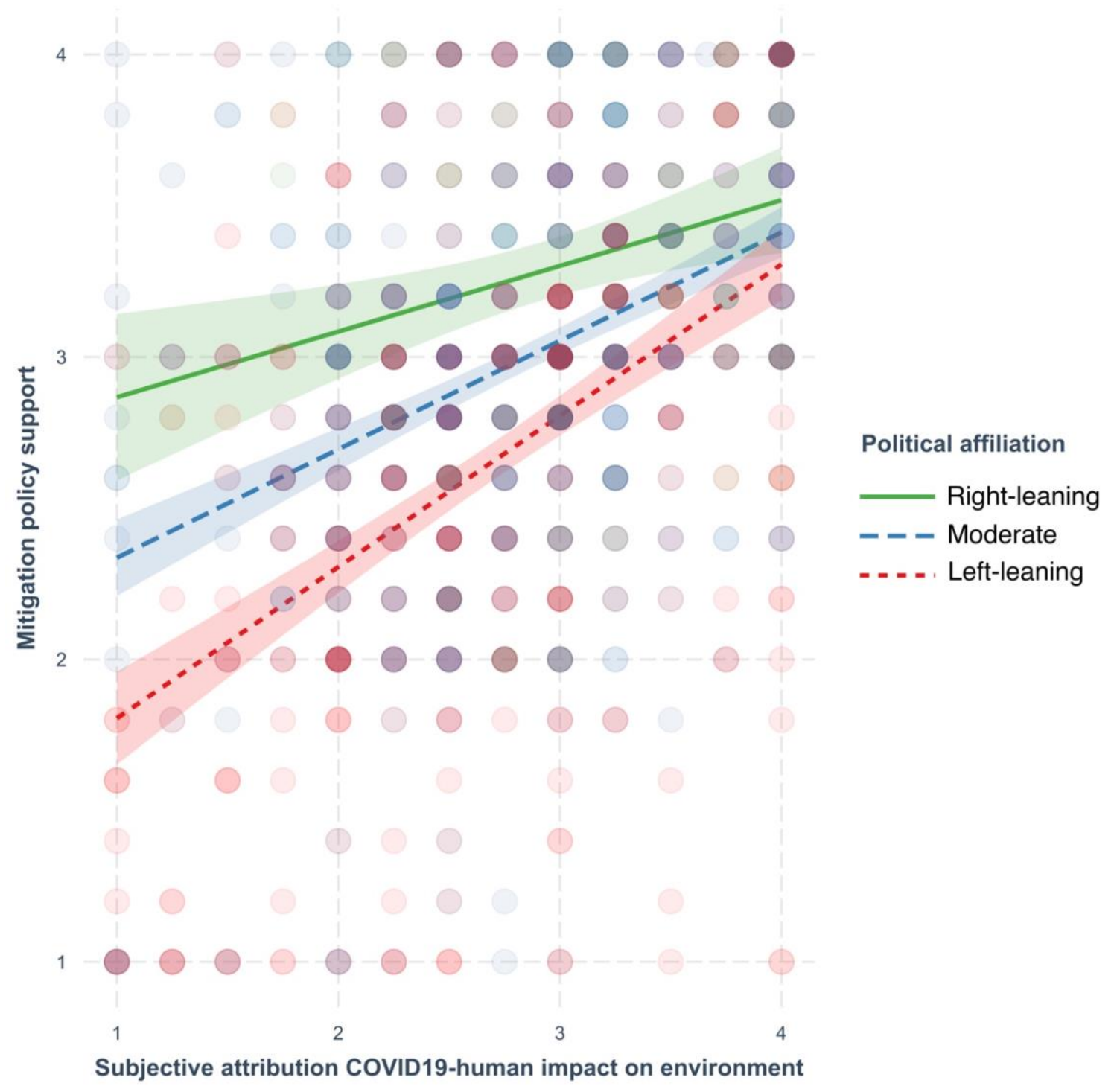

Figure 1. The plot of interaction between political affiliation and subjective attribution of infectious disease outbreaks to human impact on the environment on mitigation policy support with $95 \%$ confidence intervals. Subjective attribution and policy support were measured on a four-point scale, from $1=$ strongly disagree, $4=$ strongly agree . The effect is plotted at the three values of the moderator, -1=right-leaning, $0=$ moderate, $1=$ left-leaning. 


\section{Figure 2}

Interaction between political affiliation and subjective attribution of infectious disease outbreaks to climate change on mitigation policy.

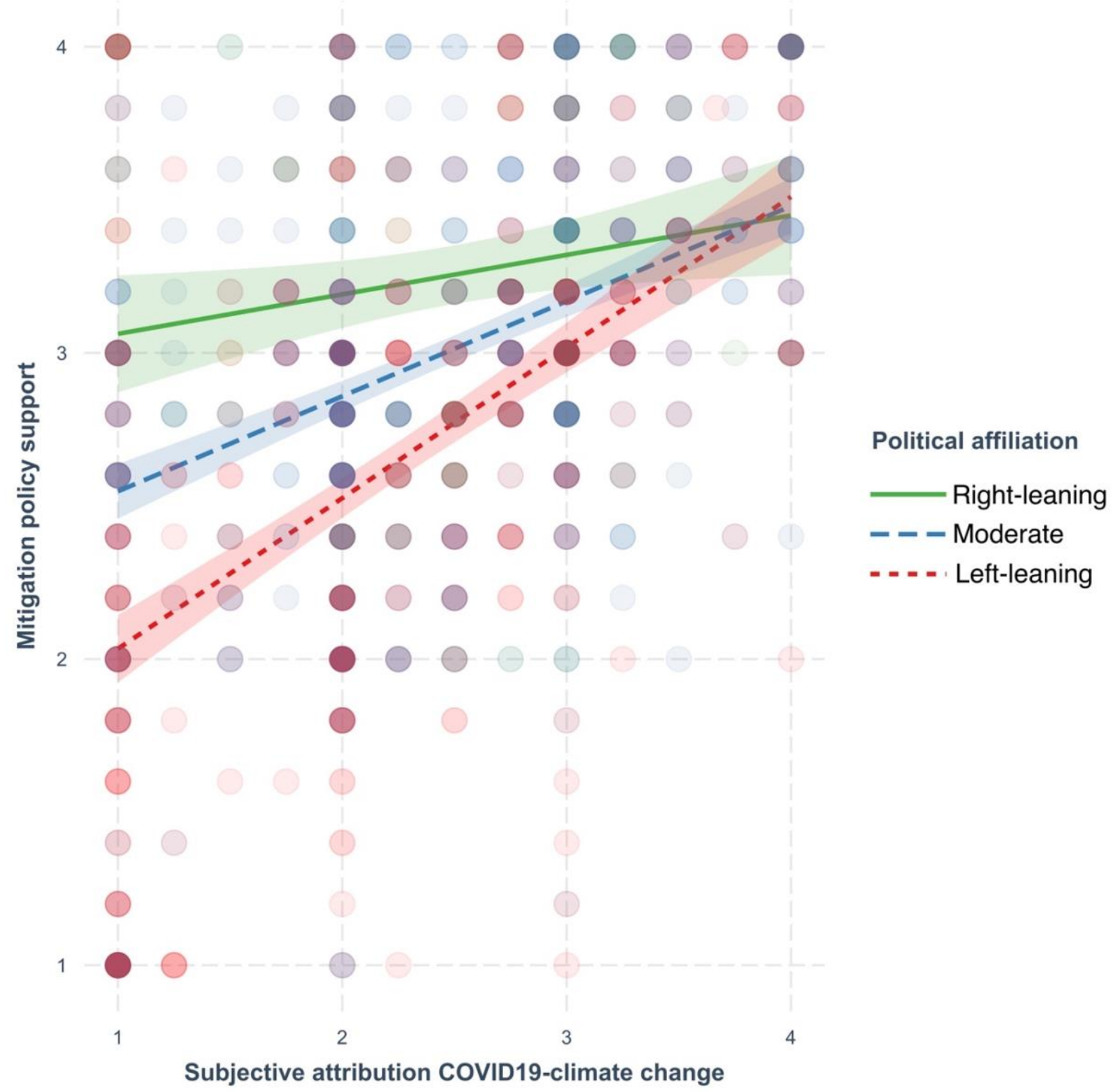

Figure 2. The plot of interaction between political affiliation and subjective attribution of infectious disease outbreaks to climate change on mitigation policy support with $95 \%$ confidence intervals. Subjective attribution and policy support were measured on a four-point scale, from $1=$ strongly disagree, $4=$ strongly agree. The effect is plotted at the three values of the moderator, $-1=$ right-leaning, $0=$ moderate, $1=$ left-leaning . 


\section{Supplementary Table 1}

Factor Analysis of Subjective Attribution

\begin{tabular}{|c|c|c|}
\hline \multirow[t]{2}{*}{ Subjective attribution item } & \multicolumn{2}{|c|}{ Factor loading } \\
\hline & 1 & 2 \\
\hline \multicolumn{3}{|l|}{$\begin{array}{l}\text { Factor 1: Subjective attribution-infectious disease } \\
\text { outbreaks with human impact on the environment }\end{array}$} \\
\hline $\begin{array}{l}\text { 1. Human impact on the environment increases the risk of } \\
\text { new infectious diseases }\end{array}$ & .45 & .71 \\
\hline $\begin{array}{l}\text { 2. Cutting forests increases the risk of new infectious } \\
\text { diseases jumping from wildlife to humans }\end{array}$ & .57 & .84 \\
\hline $\begin{array}{l}\text { 3. Rapid agricultural expansion in wildlife areas makes it } \\
\text { easier for infectious diseases to spread to humans }\end{array}$ & .53 & .89 \\
\hline $\begin{array}{l}\text { 4. Large-scale animal "factory" farms increase the risks of } \\
\text { new disease outbreaks }\end{array}$ & .39 & .79 \\
\hline \multicolumn{3}{|l|}{$\begin{array}{l}\text { Factor 2: Subjective attribution-infectious disease } \\
\text { outbreaks with climate change }\end{array}$} \\
\hline $\begin{array}{l}\text { 1. Climate change causes the spread of infectious diseases } \\
\text { to new places }\end{array}$ & .89 & .54 \\
\hline $\begin{array}{l}\text { 2. Climate change increases the risk of new disease } \\
\text { outbreaks such as the coronavirus }\end{array}$ & .94 & .53 \\
\hline $\begin{array}{l}\text { 3. Climate change is making conditions more suitable for } \\
\text { disease transmission between wildlife and humans }\end{array}$ & .91 & .54 \\
\hline $\begin{array}{l}\text { 4. Climate change will result in more pandemics such as } \\
\text { the coronavirus }\end{array}$ & .92 & .54 \\
\hline
\end{tabular}

Note: $n=1034$. The extraction method was principal axis factoring with an oblique

(direct oblimin with Kaiser Normalization) rotation. 